\title{
PERLINDUNGAN HUKUM UNTUK MEWUJUDKAN KETAHANAN PANGAN MASYARAKAT DI MASA COVID - 19
}

\author{
Debora Pasaribu, ${ }^{1}$ Rizky Karo Karo, ${ }^{2}$ \\ Dosen Fakultas Hukum Universitas Universitas Pelita Harapan \\ E-mail : debora.pasaribu@uph.edu \\ Mahasiswa Doktor Hukum Fakultas Hukum Universitas Universitas Pelita Harapan \\ E-mail : rizky.karokaro@uph.edu
}

\begin{abstract}
Covid-19 has had tremendous changes in all sectors of human life, the economy, social welfare, and food security. In this article, researchers discuss food security in Indonesia during Covid-19. Indonesian people need good food, quality food. High-quality food will make Indonesian people more ready to face Covid-19. The formulation of the researcher's problem: how is the legal protection to realize community food security in the Covid-19 period? And what kind of incentives can be given to farmers? Research methods are normative juridical methods. Researchers use secondary data relating to research topics and will be analyzed qualitatively. The results of the study are expected to provide a view to the Government where food import policies are carried out as a last resort. The government through the Ministry of Agriculture and local government must provide legal protection must be given to farmers in real form, for example providing incentives. These incentives can be in the form of cash, free fertilizer, or seeds with high quality.
\end{abstract}

Keywords: Food Security; Covid-19; Agricultural Incentives

\begin{abstract}
Abstrak
Covid-19 membawa dampak perubahan yang luar biasa dalam segala sektor kehidupan manusia, sisi ekonomi, kesejahateraan sosial, dan ketahanan pangan. Pada tulisan ini, Peneliti membahas tentang ketahanan pangan di Indonesia pada masa Covid-19. Masyarakat Indonesia memerlukan pangan yang baik, pangan yang berkualitas. Pangan yang berkualitas tinggi akan membuat masyarakat Indonesia semakin siap menghadapi Covid-19. Rumusan masalah peneliti: bagaimana perlindungan hukum untuk mewujudkan ketahanan pangan masyarakat di masa Covid-19? Dan bentuk insentif apa yang dapat diberikan kepada petani? Metode penelitian yakni metode yuridis normative. Peneliti menggunakan data sekunder yang berkaitan dengan topik Penelitian dan akan dianalisis secara deskriptif kualitatif. Hasil penelitian diharapkan dapat memberikan pandangan kepada Pemerintah dimana kebijakan impor pangan dilakukan sebagai upaya terakhir. Pemerintah melalui Kementerian Pertanian dan Pemerintah daerah wajib memberikan perlindungan hukum wajib diberikan ke petani dalam bentuk nyata, misalnya memberikan insentif. Insentif tersebut dapat berupa uang tunai, pemberian pupuk gratis, ataupun bibit dengan kualitas tinggi.
\end{abstract}

Kata Kunci : Ketahanan Pangan; Covid-19; Insentif Pertanian 


\section{Pendahuluan}

\subsection{Latar Belakang}

Seperti kita ketahui bahwa sejak akhir tahun 2019 terjadi pandemi yang melanda seluruh dunia yang dikenal dengan nama corona virus deseases (disingkat covid-19). Virus ini untuk pertama kalinya merebak di Wuhan, sebuah kota di China pada Desember 2019. Kota ini merupakan pusat industri dan transportasi di China. Dari Wuhan, virus ini terus menyebar ke seluruh dunia termasuk negara kita Indonesia. Pada saat virus corona merebak di Wuhan ada sekitar 278 orang Warga Negara Indonesia yang dijemput pulang ke Indonesia. Setelah sampai di bandara Halim Perdana Kusuma, mereka tidak dapat langsung kembali ke rumah masing-masing, tetapi sesuai protokol kesehatan yang dikeluarkan oleh Kementerian Kesehatan Republik Indonesia khususnya Direktorat Jenderal Pencegahan dan Pengendalian Penyakit mengenai Pedoman Pencegahan dan Pengendalian Corona Virus Desease (Covid-19) tanggal 27 Maret 2020, mereka harus menjalani karantina selama 14 hari untuk memutus rantai penularan virus ini dan mereka ditempatkan di Pulau Natuna. Setelah itu pemerintah mulai memberlakukan pemeriksaan atau sejenis tes kesehatan antara lain suhu badan di setiap Bandar Udara dan Pelabuhan atau pintu masuk ke Indonesia. Hal ini dimaksudkan untuk mencegah penyebaran virus yang sangat cepat dan akibatnyapun sangat luar biasa menakutkan.

Organisasi Kesehatan Dunia (WHO) pada tanggal 11 Maret 2020 resmi mengumumkan bahwa Corona Virus Disease (COVID-19) menjadi pandemic karena semakin meluas keseluruh penjuru dunia. Kemudian Pemerintah menerbitkan melalui Peraturan Menteri Kesehatan Republik Indonesia Nomor 9 Tahun 2020 Tentang Pedoman Pembatasan Sosial Berskala Besar Dalam Rangka Percepatan Penanganan Corona Virus Disease 2019 (COVID-19) tanggal 3 April 2020.

Dampak dari virus ini terutama adalah pada kesehatan masyarakat, tetapi yang kemudian sangat berdampak pada kehidupan sosial-ekonomi masyarakat. Dengan diterbitkannya aturan tentang Pembatasan Sosial Skala Besar (PSBB) maka kegiatan masyarakat yang tadinya tidak terbatas menjadi sangat terbatas. Bekerja, belajar dan ibadah harus dilakukan dari rumah (Work From Home/WFH). Pembatasan ini menyebabkan para pekerja non formal seperti pedagang kali lima, pengemudi kendaraan online dan sebagainya mulai kesulitan untuk mendapatkan pelanggan/order. Dampak lainnya terjadi pada karyawan yang bekerja di pabrik maupun di kantor. Ada yang dirumahkan, bekerja secara shift, bahkan ada yang dikenakan Pemutusan Hubungan Kerja (PHK).

Masyarakat juga diminta untuk bergotong-royong membantu warga atau tetangga mereka dengan memberikan sembako yang dikoordinir oleh Ketua RT/RW setempat. Pembatasan Sosial Berskala Besar (PSBB) yang dilakukan di beberapa propinsi lebih menyebabkan kesulitan lagi bagi masyarakat seperti tidak bisa keluar masuk tanpa ijin dari pejabat yang berwenang (harus mendapatkan Surat Ijin Keluar Masuk). Pada aspek ekonomi, dengan semakin besarnya jumlah orang yang tidak bekerja menyebabkan menurunnya daya beli masyarakat.

Hukum dan Undang-undang Tidak dapat bediri sendiri. Manusia mencptakan hukum bukan hanya untuk kepastian namun juga untuk kebahagiaan ${ }^{1}$. Menurut Satjipto Rahardjo, apakah hukum itu mengatur masyarakat semata-mata untuk

1 Nuryadi, (2016). Teori Hukum Progresif Dan Penerapannya Di Indonesia. Jurnal Ilmiah Hukum DE'JURE: Kajian Ilmiah Hukum, 1(2), 394-408. https://doi.org/10.35706/dejure.v1i2.515. Hlm. 394. 
mengatur atau untuk suatu tujuan yang lebih besar?² Selain itu, hukum juga bermanfaat untuk mewujudkan hak asasi manusia sebagaimana diamanatkan dalam Undangundang Dasar Tahun $1945^{3}$.

Pertanian yang baik, ketersediaan bibit yang baik akan menghasilkan pangan yang berkualitas tinggi. Pangan dan pertanian memiliki keterkaitan dengan banyak aspek kehidupan manusia, mulai dari soal komoditi dengan masalah, tantangan, kebijakan dan praktisknya 4 . Menurut Presiden Pertama Republik Indonesia dalam Pidatonya pada tahun 1952 di Institut Pertanian Bogor (IPB) sebagaimana dikutip oleh Made Oka bahwa ketahanan pangan pada tingkat nasional melemah karena 5 (lima) faktor yakni: (1). Menurunnya jumlah dan mutu sumber daya alam, terutama sumber daya air yang menjadi modal pertanian pangan; (2). Perubahan iklim dan dampaknya pada produksi bahan pangan; (3). Prasarana distribusi yang tidak memadai terutama di daerah terpencil; (4). Peraturan yang tidak memadai yang menjamin sistem dan distribusi perdagangan yang jujur, bertanggung jawab dan aman (termasuk impor beras); (5). Besarnya jumlahnya penduduk yang belum mampu merasakan ketahanan pangan mereka sendiri ${ }^{5}$. Makanan yang berkualitas tinggi akan bermanfaat bagi kesehatan tubuh, dan dapat menghindari penggunaan bahan pengawet yang tinggi dan dapat merusak kesehatan manusia ${ }^{6}$.

Ada dugaan bahwa pengaruh globalisasi dengan ideologi neoliberalisme telah memaksakan petani dan Negara membuat pilihan yang tidak nyaman dan saling bertentangan. Pakar ekonomi pertanian, Francis Wahono, menilai bahwa pilihan kebijakan dan praktik pemerintah banyak yang melantarkan rakyat, termasuk petani ${ }^{7}$. Menurut Wahono, "suatu negara akan rapuh eksistensinya bila tidak dapat menyelenggarakan dan menggerakkan rakyat untuk mengadakan pangan". 8

Payung hukum yang mengatur pangan di Indonesia yakni Undang-undang No. 18 Tahun 2012 tentang Pangan (selanjutnya disebut UU Pangan). Menurut Jamin Ginting, salah satu fungsi Undang-undang adalah sebagai bentuk negara hukum di Indonesia ${ }^{9}$. Salah satu pertimbangan dibentuknya UU Pangan yakni bahwa negara berkewajiban mewujudkan ketersediaan, keterjangkauan, dan pemenuhan konsumsi Pangan yang cukup, aman, bermutu, dan bergizi seimbang, baik pada tingkat nasional maupun daerah hingga perseorangan secara merata di seluruh wilayah Negara Kesatuan Republik Indonesia sepanjang waktu dengan memanfaatkan sumber daya,

${ }^{2}$ Satjipto Rahardjo, Penegakan Hukum Progresif, (2010), Jakarta; Kompashlm. 36.

3 A Budianto, RK Karo. (2021), Marapu Customary Law Reconstruction Through The

Establishment Of Regional Regulations As An Attempt Of Human Rights Protection Againts The Native Sumba Society. Multicultural Education, 2021. DOI: $10.5281 /$ ZENODO.4767980

4 Sulhani Hermawan. Tinjauan Keadilan Sosial Terhadap Hukum Tata Pangan Indonesia.(2018), Mimbar Hukum Volume 24, No. 3, Oktober, Hlm. 499.

5 Made Oka Adnyana. (2008), Lintasan Dan Marka Jalan Menuju Ketahanan Pangan Terlanjutkan Dalam Era Perdagangan Bebas. Pengembangan Inovasi Pertanian 1 (1). 17-46. Hlm. 143.

${ }^{6}$ Budianto, A. (2018). Formalin Dalam Kajian Undang-Undang Kesehatan; Undang-Undang Pangan Dan Undang-Undang Perlindungan Konsumen Formalin In Health, Food And Consumer Protection Laws Studies. Jurnal Legislasi Indonesia, 8(1), 151-172.

7 Francis Wahono. (2011), Ekonomi Politik Pangan. Jakarta: Bina Desa dan Yogyakarta: Cinde Books.

8 Ibid.

9 Jamin Ginting, dan Helfinsi Raportina, (2021), Implikasi Hukum Putusan Mahkamah Konstitusi Nomor 16/PUU-XVIII/2020 Terhadap Notaris Sebagai Saksi Dalam Kasus Pidana. Law Review Volume XX, No. 2, Novemeber. Hlm. 222. 
kelembagaan, dan budaya lokal. Definsi ketahanan pangan berdasarkan Pasal 1 Angka 4 UU Pangan yakni kondisi terpenuhinya Pangan bagi negara sampai dengan perseorangan, yang tercermin dari tersedianya Pangan yang cukup, baik jumlah maupun mutunya, aman, beragam, bergizi, merata, dan terjangkau serta tidak bertentangan dengan agama, keyakinan, dan budaya masyarakat, untuk dapat hidup sehat, aktif, dan produktif secara berkelanjutan.

Pangan menjadi sektor yang sangat penting di saat pandemic Corona, khususnya di Indonesia. Presiden Republik Indonesia, Bapak JokoS Widodo telah menekankan agar ketersediaan pangan food security, sangat penting bagaimana dengan kesiapan produksi pangan kita, bagaimana kesiapan industri pengolahan pasca panen, bagaimana efisiensi rantai pasok dan distribusi, semua harus kita lihat lagi dan kita harus siapkan strategi besar menghadapi itu ke depan ${ }^{10}$. Sebagaimana dicatat oleh katadata.co.id (18 Mei 2020), Presiden Joko Widodo telah mengingatkan kepada Kepala Daerah, Kementerian Pertanian tentang bahaya deficit pangan di Indonesia pada pertengahan April dan kedua pada 28 April 2020. Menurut Kepala Badan Ketahanan Pangan (BKP) Kementerian Pertanian yang menjabat pada tahun 2020 mengungkapkan bahwa hingga Mei 2020 terdapat 7 (tujuh) provinsi yang mengalami deficit beras akan dapat ditutup oleh 27 (dua puluh tujuh) provinsi yang mengalami surplus ${ }^{11}$. Tujuan Penelitian ini adalah sejalan dengan pokok-pokok permasalahan tersebut, maka tujuan penelitian adalah untuk mengetahui dan menganalisis perlindungan hukum untuk mewujudkan ketahanan pangan masyarakat di masa Covid-19.

\subsection{Rumusan Masalah}

Berdasarkan latar belakang diatas, rumusan masalah yang Peneliti angkat adalah bagaimana perlindungan hukum untuk mewujudkan ketahanan pangan masyarakat di masa Covid-19? Kedua, bentuk insentif seperti apa yang dapat diberikan kepada petani agar menghasilkan pangan yang berkualitas?

\section{Metode Penelitian}

\subsection{Sifat Penelitian}

Peneliti menggunakan peneltian hukum normatif. Penelitian hukum normatif adalah suatu proses menemukan satu prinsip hukum, doktrin hukum untuk menjawab permasalahan yang dihadapi. Penelitian ini digunakan untuk menghasilkan argumentasi, atau konsep baru dalam menyelesaikan masalah yang dihadapi. ${ }^{2}$

\subsection{Teknik Pegumpulan Data}

Data dalam Penelitian ini adalah data sekunder. The secondary data referred to data obtained indirectly, meaning that the data is only material, either in the form of legislation, books, research results, study results, and others ${ }^{13}$. Data sekunder Peneliti kumpulkan dengan cara

10 Badan Ketahanan Pangan Kementerian Pertanian "Kementan Siapkan Strategi Ketahanan Pangan di Tengah Pandemi Covid-19 http://bkp.pertanian.go.id/blog/post/kementan-siapkan-strategiketahanan-pangan-di-tengah-pandemi-covid-19 (diakses tanggal 12 Juli 2020)

${ }_{11}$ M. Ahsan "Langkah Bulog \& Kementan Atasi Ancaman Defisit Pangan Saat Pandemi" https://katadata.co.id/berita/2020/05/18/langkah-bulog-kementan-atasi-ancaman-defisit-pangan-saatpandemi (diakses tanggal 12 Juli 2020)

12 Peter Mahmud Marzuki, (2005) Penelitian Hukum, Bandung, Kencana, hlm.35

13 Budianto, A. (2020). Legal Research Methodology Reposition in Research on Social Science. International Journal of Criminology and Sociology, 9, 1339-1346. 
studi pustaka, yang meliputi buku, jurnal, hasil penelitian yang relevan, peraturan hukum yang relevan. Peneliti menggunakan bahan hukum primer antara lain seperti:

a) Undang-Undang Dasar Negara Republik Indonesia Tahun 1945

b) Undang-Undang No. 24 tahun 2007 tentang Penanggulangan Bencana

c) Undang-Undang Nomor 41 Tahun 2009 tentang Cegah Alih Fungsi Lahan Pertanian Demi Ketahanan Pangan

d) Undang-undang No. 41 Tahun 2009 tentang Perlindungan Lahan Pertanian Pangan Berkelanjutan

e) Undang-Undang Nomor 18 Tahun 2012 tentang Pangan

f) Undang-Undang Nomor 6 Tahun 2014 tentang Desa

g) Peraturan Pemerintah, Keputusan Presidan, Peraturan Menteri dan peraturan lainnya yang terkait dengan materi yang dibahas dalam tulisan ini.

Peneliti menggunakan bahan hukum sekunder untuk memberi penjelasan mengenai bahan hukum primer yang didapatkan dari artikel, jurnal. Peneliti menggunakan bahan hukum tersier untuk memperjelas kelengkapan informasi bahan hukum primer dan sekunder, seperti kamus.

\section{Hasil dan Pembahasan}

\subsection{Upaya Pencegahan Keterbatasan Pangan Pada Masa Covid-19 dan Fungsi Insentif}

Pangan adalah segala sesuatu yang berasal dari sumber hayati produk pertanian, perkebunan, kehutanan, perikanan, peternakan, perairan, dan air, baik yang diolah maupun tidak diolah yang diperuntukkan sebagai makanan atau minuman bagi konsumsi manusia, termasuk bahan tambahan pangan, bahan baku pangan, dan bahan lainnya yang digunakan dalam proses penyiapan, pengolahan, dan/atau pembuatan makanan atau minuman. ${ }^{14}$. Ketahanan Pangan adalah kondisi terpenuhinya pangan bagi negara sampai dengan perseorangan, yang tercermin dari tersedianya pangan yang cukup, baik jumlah maupun mutunya, aman, beragam, bergizi, merata, dan terjangkau serta tidak bertentangan dengan agama, keyakinan, dan budaya masyarakat, untuk dapat hidup sehat, aktif, dan produktif secara berkelanjutan ${ }^{15}$.

Keberhasilan kegiatan KRPL memerlukan koordinasi antar berbagai pemangku kepentingan mulai dari pusat sampai ke daerah. Di tingkat pusat, khususnya yang terkait dengan kebijakan, Badan Ketahanan Pangan sebagai penanggung jawab kegiatan KRPL berkoordinasi dengan kementerian/lembaga terkait antara lain Kementerian Desa dan PDT, Kementerian Kesehatan, Kementerian Dalam Negeri, Kemenristek Dikti dan organisasi kemasyarakatan lainnya. Di tingkat provinsi dan kabupaten/kota, Kepala Dinas/Unit Kerja yang menangani Ketahanan Pangan sebagai penanggung jawab pelaksanaan kegiatan berkoordinasi dengan dinas/instansi terkait seperti Balai Pengkajian Teknologi Pertanian (BPTP), Dinas Pertanian, Dinas Kesehatan, Dinas Pendidikan dan Kebudayaan, Dinas Perdagangan, Dinas Peternakan dan Perikanan,

${ }^{14}$ Badan Ketahanan Pangan. (2019), Petunjuk Teknis Pengembangan Kawasan Rumah Pangan Lestari, Jakarta: Kementerian Pertanian RI Badan Ketahanan Pangan Pusat Penganekaragaman Konsumsi dan Keamanan Pangan, Hlm. 3.

15 Ibid. 
perguruan tinggi dan organisasi kemasyarakatan lainnya seperti PKK tingkat provinsi, kabupaten/kota, kecamatan, kelurahan dan desa ${ }^{16}$

Seperti kita ketahui bahwa sejak akhir tahun 2019 wabah virus corona (covid-19) melanda seluruh negara di dunia termasuk Indonesia. Tercatat 213 negara yang terkena virus corona ini. ${ }^{17}$ Wabah Corona Virus Desease (disingkat menjadi Covid-19) ini sangat berdampak besar bukan hanya kesehatan, namun aspek sosial ekonomi sangat terpengaruh dengan virus ini. WHO (Lembaga Kesehatan Dunia) mengemukakan bahwa wabah Covid-19 ini sebagai pandemic. ${ }^{18}$ Wabah ini telah merusak tatanan kesehatan, social, ekonomi sebagian besar negara-negara terdampak termasuk Indonesia Pandemi dalam Kamus Besar Bahasa Indonesia adalah wabah yang berjangkit serempak di mana-mana, meliputi daerah geografi yang luas.

Masyarakat saat ini terbebani dengan kebutuhan hidup sehari-hari terutama masyarakat pedesaan, untuk itu Pemerintah khususnya pemerintah daerah menyiapkan perangkat aturan bagaimana menghadapi wabah covid-19 ini dengan berbagai penyuluhan agar masyarakat tetap tercukupi kebutuhan pangannya sehari-hari, misalnya memberikan penyuluhan tentang protocol kesehatan yang harus ditaati setiap orang terutama pada masyarakat petani di pedesaan yang paling terdampak wabah virus corona ini, oleh karena itu Pemerintah berkewajiban untuk memberikan bantuan pangan, penyuluhan pertanian agar tetap bisa produktif. misalnya menanam sayuran dan berbagai jenis palawija dilahan rumah sebagai pangan alternative pengganti beras.

Menurut Phillipus M. Hadjon bahwa perlindungan hukum bagi rakyat sebagai tindakan pemerintah yang bersifat preventif dan represif. Perlindungan hukum yang preventif bertujuan untuk mencegah terjadinya sengketa, yang mengarahkan tindakan pemerintah bersikap hati-hati dalam pengambilan keputusan bwedasarkan diskresi, dan perlindungan yang represif bertujuan untuk menyelesaikan terjadinya sengketa, termasuk penangananya di lembaga peradilan ${ }^{19}$. Menurut Satjipto Raharjo bahwa perlindungan hukum adalah memberikan pengayoman terhadap hak asasi manusia (HAM) yang dirugikan orang lain dan perlindungan itu di berikan kepada masyarakat agar dapat menikmati semua hak-hak yang diberikan oleh hukum²0.

Berdasarkan Pasal 1 Angka 29 UU Pangan, definisi krisis pangan yakni kondisi kelangkaan Pangan yang dialami sebagian besar masyarakat di suatu wilayah yang disebabkan oleh, antara lain, kesulitan distribusi Pangan, dampak perubahan iklim, bencana alam dan lingkungan, dan konflik sosial, termasuk akibat perang.

Berdasarkan Pasal 44 ayat (1) UU Pangan bahwa Pemerintah dan Pemerintah Daearh berkewajiban melakukan tindakan untuk mengatasi krisis pangan. Tindakan yang dimaksud adalah dilakukan dalam bentuk: a. pengadaan, pengelolaan, dan penyaluran Cadangan Pangan Pemerintah dan Pemerintah Daerah; b. mobilisasi Cadangan Pangan Masyarakat di dalam dan antardaerah; c. menggerakkan partisipasi

16 Ibid. hlm. 17.

17 Berlianto, "Menyebar ke 213 Negara, Covid-19 Menginfeksi 4,9 juta orang" https://international.sindonews.com/read/37888/40/menyebar-ke-213-negara-covid-19-menginfeksi-49juta-orang-1589929509

${ }^{18} \mathrm{https}: / / \mathrm{www} . c n n i n d o n e s i a . c o m /$ internasional (12/03/20)

19 Philpus M. Hadjon. (1987), Perlindungan Hukum Bagi Rakyat Indonesia. Surabaya: PT Bina Ilmu, Hlm. 29.

${ }^{20}$ Satjipto Raharjo. (2000), Ilmu Hukum. Bandung: PT Citra Aditya Bakti, Hlm. 53. 
masyarakat; dan/atau d. menerapkan teknologi untuk mengatasi Krisis Pangan dan pencemaran lingkungan ${ }^{21}$.

Berdasarkan Pasal 37 Undang-undang Nomor 41 Tahun 2009 tentang Perlindungan Lahan Pertanian Pangan Berkelanjutan (UU 41/2009) bahwa pengendalian lahan pertanian pangan berkelanjutan dilakukan oleh Pemerintah dan Pemerintah Daerah melalui pemberian: a. insentif; b. disinsentif; c. mekanisme perizinan; d. proteksi; dan e. penyuluhan. Insentif diberikan kepada petani berupa: a. keringanan Pajak Bumi dan Bangunan; b. pengembangan infrastruktur pertanian; $c$. pembiayaan penelitian dan pengembangan benih dan varietas unggul; $d$. kemudahan dalam mengakses informasi dan teknologi; e. penyediaan sarana dan prasarana produksi pertanian; f. jaminan penerbitan sertifikat bidang tanah pertanian pangan melalui pendaftaran tanah secara sporadik dan sistematik; dan/atau g. penghargaan bagi petani berprestasi tinggi ${ }^{22}$. Selain itu, Pemerintah dapat memberikan insentif dalam bentuk pengalokasian anggaran secara khusus atau bentuk lainnya kepada pemerintah daerah provinsi dan pemerintah daerah kabupaten/kota sesuai dengan ketentuan peraturan perundang-undangan ${ }^{23}$. Dan Pemerintah daerah provinsi dapat memberikan insentif dalam bentuk pengalokasian anggaran secara khusus atau bentuk lain sesuai dengan ketentuan peraturan perundang-undangan²4.

Pemeberian insentif tersebut dijalankan berdasarkan pertimbangan: a. jenis Lahan Pertanian Pangan Berkelanjutan; b. kesuburan tanah; c. luas tanam; d. irigasi; e. tingkat fragmentasi lahan; f. produktivitas usaha tani; g. lokasi; h. kolektivitas usaha pertanian; dan/atau i. praktik usaha tani ramah lingkungan. Penetapan kriteria dan status Krisis Pangan dilakukan oleh Pemerintah dan/atau Pemerintah Daerah sesuai dengan skala krisis ${ }^{25}$. Penetapan sebagaimana dimaksud pada ayat (1) dilakukan oleh: a. Presiden untuk skala nasional; b. gubernur untuk skala provinsi; dan c. bupati/walikota untuk skala kabupaten/kota ${ }^{26}$. Ketentuan lebih lanjut mengenai penetapan kriteria dan status Krisis Pangan sebagaimana dimaksud pada ayat (1) diatur dengan atau berdasarkan pada Peraturan Pemerintah ${ }^{27 .}$

Menurut penelusuran Peneliti, Pemerintah RI masih bisa mengatasi, mempersiapkan stok pangan bagi rakyat Indonesia di kala Covid-19. Namun banyak stakeholders memperkerikan apabila Negara tidak sigap dan tidak siap, maka Covid-19 dapat menimbulkan potensi krisis pangan, namun kita berharap hal ini tidak terjadi. Menurut Menteri Desa dan PDTT (Kabinet Indonesia Maju) berpendapat pandemi Covid-19 berpotensi mengakibatkan terjadinya kesulitan tenaga kerja, akan kesulitan juga dalam mengimpor bahan pangan karena masing-masing Negara di dunia tentu

\footnotetext{
${ }^{21}$ Pasal 44 ayat (2) UU Pangan

22 Pasal 38 UU 41/2009

${ }^{23}$ Pasal 39 ayat (1) UU 41/2009

${ }^{24}$ Pasal 39 ayat (2) UU 41/2009

${ }^{25}$ Pasal 45 ayat (1) UU Pangan

${ }^{26}$ Pasal 45 ayat (2) UU Pangan

${ }^{27}$ Pasal 45 ayat (3) UU Pangan
} 
akan memprioritaskan kebutuhan pangan masyarakatnya terlebih dahulu28. Namun, diperlukan sinergitas, gotong royong dari pelbagai pihak, orang per orangan, Lembaga Swadaya Masyarakat (LSM), Pemerintah Daerah Provinsi/Kabupaten. LSM ikut serta dalam membentuk rancangan alternatif bagi Pemerinta Daerah dalam program tertentu, misalnya mengoptimalkan potensi lokal dan menciptakan infrastruktur yang bermanfaat bagi rakyat, mendorong terbukanya peluang terhadap sumber daya ${ }^{29}$.

\subsection{Tugas Dan Fungsi Kementerian Pertanian dan Badan Ketahanan Pangan}

Kementerian Pertanian (selanjutnya disebut Kementan) sebagai Kementerian yang bertanggung jawab dan memiliki peran untuk menjaga ketahanan pangan di masa Covid-19. Kementan telah menyiapkan strategi dalam menghadapi tantangan ketahanan pangan di masa Covid-19 untuk meningkatkan produksi pangan dan menjaga agar petani tetap berproduksi. Kementan memberian bantuan subisidi pengangkutan pangan dari daerah surplus ke daerah minus, sehingga pasokan pangan dapat menjangkau seluruh wilayah Indonesia. Upaya Kementan dalam membantu pendistribusian ini bertujuan agar hasil panen petani dapat terserap pasar dengan harga yang wajar di tengah pandemi, sehingga petani tetap bersemangat menanam dan berproduksi30.

Menurut pendapat Peneliti, Kementan memiliki fungsi penting sebagai penggerak kelompok petani, kelompok masyarakat untuk tetap produktif di masa Covid-19 ini. Kementan harus mengawal usaha petani, dan memberikan pendampingan secara langsung. Kementan melalui Badan Ketahanan Pangan (selanjutnya disebut BKP) menggerakkan Pasar Mitra Tani yang ada di seluruh provinsi, pasar mitra tani di seluruh Indonesia mampu memperpendek mata rantai distribusi, karena bahan pangan dipasok langsung dari petani melalui kegiatan Pengembangan Usaha Pangan Masyarakat (PUPM), sehingga konsumen mendapat pangan berkualitas dengan harga terjangkau. BKP juga melakukan pemantauan terus menerus ke seluruh provinsi melalui quick count dan teleconference bersama Dinas Pangan diseluruh Provinsi setiap minggu sehingga dapat diketahui kondisi ketahanan pangan di setiap daerah ${ }^{31}$.

Berdasarkan kewenangannya, Badan Ketahanan Pangan juga memiliki peranan penting seperit Kementan, dan memiliki tugas serta fungsi yang lebih khusus untuk meningkatkan ketahanan pangan. Badan Ketahanan Pangan memiliki tugas dan fungsi sebagai berikut: Dan fungsi BKP yakni: 1. Koordinasi, pengkajian, penyusunan kebijakan, pemantauan, dan pemantapan di bidang ketersediaan pangan, penurunan kerawanan pangan, pemantapan distribusi pangan dan akses pangan, penganekaragaman konsumsi pangan, dan peningkatan keamanan pangan segar; 2. Penyusunan norma, standar, prosedur, dan kriteria di bidang ketersediaan pangan,

28 Dani Prabowo "Cegah Krisis Pangan karena Pandemi Covid-19, Ini yang Dilakukan Kemendes” https://nasional.kompas.com/read/2020/05/14/15455321/cegah-krisis-pangan-karenapandemi-covid-19-ini-yang-dilakukan-kemendes (diakses tanggal 12 Juli 2020)

${ }^{29}$ Ina Heliany (2018). Peranan Lembaga Swadaya Masyarakat (LSM) Terhadap Pembangunan Politik Dan Demokrasi Di Indonesia. Jurnal Ilmiah Hukum DE'JURE: Kajian Ilmiah Hukum, 3(1), 131146. https://doi.org/10.35706/dejure.v3i1.1890 . Hlm. 140.

${ }^{30}$ Badan Ketahanan Pangan Kementerian Pertanian "Kementan Siapkan Strategi Ketahanan

Pangan di Tengah Pandemi Covid-19 http://bkp.pertanian.go.id/blog/post/kementan-siapkan-strategiketahanan-pangan-di-tengah-pandemi-covid-19 (diakses tanggal 12 Juli 2020)

${ }^{31}$ Ibid. 
penurunan kerawanan pangan, pemantapan distribusi pangan dan akses pangan, penganekaragaman konsumsi pangan, dan peningkatan keamanan pangan segar; 3 . Pelaksanaan bimbingan teknis dan supervisi di bidang ketersediaan pangan, penurunan kerawanan pangan, pemantapan distribusi pangan dan akses pangan, penganekaragaman konsumsi pangan, dan peningkatan keamanan pangan segar; 4 . Pelaksanaan evaluasi dan pelaporan di bidang ketersediaan pangan, penurunan kerawanan pangan, pemantapan distribusi pangan dan akses pangan, penganekaragaman konsumsi pangan, dan peningkatan keamanan pangan segar; 5 . Pelaksanaan administrasi Badan Ketahanan Pangan; dan 6. Pelaksanaan fungsi lain yang diberikan oleh Menteri ${ }^{32}$.

Menurut Kepala BKP, stok awal April sebesar 3,45 juta ton cukup untuk memenuhi kebutuhan wilayah yang deficit. Bedasarkan perkiraan ketersediaan pangan nasional Kementan, surplus beras hingga Juni 2020 mencapai 6,4 juta ton, jagung surplus 1,01 juta ton, bawang merah surplus 330.384 ton. Delapan komoditas lain, yakni bawang putih, cabai merah besar, cabai rawit, daging sapi, daging kerbau, telur ayam, gula pasir, dan minyak goreng juga diperkirakan surplus. Agung menyatakan, defisit di beberapa daerah merupakan hal wajar dan tak perlu dikhawatirkan. Hal ini karena masa panen dan kualitas panen di beberapa daerah selalu berbeda di setiap tahunnya. Oleh karena itu, Kementan akan terus menjaga distribusi dan pasokan pangan di negeri ini merata ${ }^{33}$. Salah satu cara yang dilakukan adalah dengan mengirim cabai merah dan cabai rawit dari Jateng dan Jatim ke Sumbar dan Jambi pada pekan lalu. Kementan juga akan mengangkut pangan untuk Sulut, Maluku, Maluku Utara, dan Papua. Kementan melaksanakan pula operasi pasar murah di setiap provinsi dan mendorong pasar mitra tani yang ada di setiap provinsi mengoptimalkan layanan pesan antara secara daring ${ }^{34}$.

\subsection{Perlindungan Hukum Mewujudkan Ketahanan Pangan di Indonesia}

Organisasi Kesehatan Dunia (WHO) pada tanggal 11 Maret 2020 resmi mengumumkan bahwa Corona Virus Disease (COVID-19) menjadi pandemi karena wabah ini menyebar keseluruh penjuru dunia. Pengertian pandemi menurut Kamus Besar Bahasa Indonesia (KBBI) adalah wabah yang berjangkit serempak dimana-mana meliputi daerah geografi yang luas. Untuk menyatakan bahwa Covid-19 adalah pandemi, Presiden selaku Kepala Pemerintahan mengeluarkan penetapan pandemi Covid-19 sebagai pandemi melalui Keputusan Presiden Nomor 12 Tahun 2O2O tanggal 13 April 2020 Tentang Penetapan Bencana Non Alam Penyebaran Corona Virus Desease 2019 (Covid 19) Sebagai Bencana Nasional.

Penetapan pandemi melalui Keputusan Presiden Nomor 12 Tahun 2020 tanggal 13 April 2020 Tentang Penetapan Bencana Non Alam Penyebaran Corona Virus Desease 2019 (Covid 19) sebagai Bencana Nasional sesuai pula dengan bunyi Undang-Undang UU Nomor 24 Tahun 2007 tentang Penanggulangan Bencana Bab I Pasal I Ketentuan Umum yang berbunyi sebagai berikut:"Status keadaan darurat bencana adalah suatu keadaan yang ditetapkan oleh Pemerintah untuk jangka waktu tertentu atas dasar rekomendasi Badan yang diberi tugas untuk menanggulangi bencana:. Dengan pasal

32 Badan Ketahanan Pangan, "Tugas Fungsi” http://bkp.pertanian.go.id/tugas-fungsi (diakses tanggal 12 Juli 2020)

${ }^{33}$ M. Ahsan Ridhoi "Langkah Bulog \& Kementan Atasi Ancaman Defisit Pangan Saat Pandemi” https://katadata.co.id/berita/2020/05/18/langkah-bulog-kementan-atasi-ancaman-defisit-pangan-saatpandemi (diakses tanggal 12 Juli 2020)

${ }^{34}$ Ibid. 
tersebut maka penetapan pandemi diterbitkan/dikeluarkan oleh Presiden selaku Kepala Pemerintahan.

Pasca Keputusan Presiden Nomor 12 Tahun 2O2O tanggal 13 April 2020 Tentang Penetapan Bencana Non Alam Penyebaran Corona Virus Desease 2019 (Covid 19), Presiden juga mengeluarkan Keputusan Presiden Nomor 7 Tahun 2O2O Tentang Gugus Tugas Percepatan Penanganan Corona Virus Desease 2019 (Covid-19) pasal 8 tentang Susunan keanggotaan Gugus Tugas Percepatan Penanganan COVID-19 Presiden melakukan langkah-langkah dengan memerintahkan kepala daerah mulai dari provinsi hingga kabupaten dan kota menetapkan situasi penyebaran Covid-19 di wilayahnya dengan berkonsultasi dengan Badan Nasional Penanggulangan Bencana (BNPB). "Siaga darurat ataukah tanggap darurat bencana non alam, berdasarkan status kedaruratan daerah tersebut," kata Presiden di Istana Bogor, Minggu (15/03). Seluruh kegiatan/aktifitas manusia dilakukan dirumah saja seperti bekerja, sekolah, ibadah dan menunda kegiatan-kegiatan yang sifatnya mengumpulkan banyak orang. Setiap orang harus menjaga jarak (social distancing). ${ }^{35}$

Masyarakat yang terjangkit wabah covid-19 ini sudah menyebar hampir keseluruh wilayah/propinsi di Indonesia. Sampai dengan tulisan ini dibuat tercatat jumlah orang yang terdampak covid-19 adalah sebagai berikut meninggal 2.198 orang, sembuh 15.123 orang, positif 39.294 orang. Data lihat dari Gugus tugas Covid-19 per hari ini Senin, 15 Juni 2020. Pada akhirnya Pemerintah memutuskan membuat keputusan mengenai penetapan sebagai Bencana Nasional dengan mengacu kepada Pasal 7 ayat (2) UU Nomor 24 tahun 2007 tentang Penanggulangan Bencana disebutkan bahwa penetapan status dan tingkat bencana nasional dan daerah memuat indikator meliputi jumlah korban, kerugian harta benda, kerusakan prasarana dan sarana; cakupan luas wilayah yang terkena bencana, dan dampak sosial ekonomi yang ditimbulkan. Ayat (3) menyatakan, ketentuan lebih lanjut mengenai penetapan status dan tingkatan bencana sebagaimana dimaksud pada ayat (2) diatur dengan Peraturan Presiden (Perpres), maka pemerintah mengeluarkan Keppres Nomor 12 Tahun 2O2O tanggal 13 April 2020 Tentang Penetapan Bencana Non Alam Penyebaran Corona Virus Desease 2019 (Covid 19) Sebagai Bencana Nasional.

FAO (Organisasi Pangan dan Pertanian Dunia) sudah mengingatkan bahwa wabah covid-19 ini bisa menyebabkan krisis pangan dunia. Dengan dinyatakannya sebagai Bencana Nasional, maka Pemerintah wajib menyediakan kebutuhan dasar pangan masyarakat (sesuai dengan bunyi pasasl 6 UU nomor 6 tahun 2018 Tentang Kekarantinaan Kesehatan yang berbunyi: "Pemerintah Pusat dan Pemerintah Daerah bertanggung jawab terhadap ketersediaan sumber daya yang diperlukan dalam penyelenggaraan Kekarantinaan Kesehatan"). Dari permasalahan tersebut di atas beban Pemerintah semakin besar dalam mewujudkan ketersediaan pangan, sementara anggaran yang disediakan untuk bantuan bencana tidak terlalu besar mengingat wabah ini sudah terjadi cukup lama. ${ }^{36}$ Dalam hal inilah gotong royong dan partisipasi masyarakat sangat dibutuhkan. Hal ini sesuai pula dengan konsiderans menimbang huruf b pada UU Nomor 18 Tahun 2012 Tentang Pangan yang menyebutkan "bahwa negara berkewajiban mewujudkan ketersediaan, keterjangkauan, dan pemenuhan konsumsi pangan yang cukup, aman, bermutu, dan bergizi seimbang, baik pada tingkat nasional maupun daerah hingga perseorangan secara merata di seluruh wilayah Negara

\footnotetext{
35 https://www.bbc.com/indonesia/indonesia-51897307)16-03-2020

${ }^{36}$ Peraturan Pemerintah Nomor 22 Tahun 2008
} 
Kesatuan Republik Indonesia sepanjang waktu dengan memanfaatkan sumber daya, kelembagaan, dan budaya lokal".

Menurut analisis Peneliti, pemberdayaan masyarakat desa harus segera dilakukan. Dana desa harus segera dikeluarkan untuk pemenuhan kebutuhan masyarakat desa, termasuk juga bantuan langsung kepada petani. Dana desa yang diberikan kepada petani dapat dilakukan dalam bentuk pinjaman ataupun subsidi mengingat pada masa Covid-19 ini daya beli masyarakat menurun. Pemberdayaan masyarakat desa dalam mewujudkan ketahanan pangan sebagaimana uraian di atas, dengan mengolah potensi alam kita, tentu beban pemerintah akan menjadi sedikit ringan. Selain itu, ketergantungan pada beras sebagai makanan pokok dapat dialihkan misalnya dengan sagu, singkong atau jagung. Petani mulai membudidayakan tanaman pengganti beras dimaksud untuk memenuhi kebutuhan pangan masyarakat. Oleh karenanya substitusi bahan pangan pokok beras juga harus semakin sering disosialisasikan.

Menurut Ali Khomsan (Guru Besar Departemen Gizi Masyarakat IPB) bahwa Ketahanan pangan keluarga menyangkut tiga hal penting, yaitu ketersediaan, akses, dan konsumsi pangan. Aspek ketersediaan pangan tergantung pada sumber daya alam, fi sik, dan manusia. Di tengah wabah covid-19, ketersediaan juga terkendala oleh terbatasnya pilihan pangan di pasaran, berkurangnya tukang sayur keliling, dan banyaknya warung penjual makanan kaki lima yang tutup. Sementara itu, akses pangan hanya dapat terjadi apabila rumah tangga mempunyai penghasilan yang cukup. Ketahanan gizi merupakan cerminan intake gizi dan status gizi masyarakat yang menjadi input bagi terbentuknya individu yang sehat. Banyak faktor yang menentukan ketahanan gizi. Kemiskinan yang menyebabkan sulitnya akses pangan diyakini sebagai faktor terpenting yang menghalangi terwujudnya ketahanan gizi yang maksimal37.

Senada dengan Ali Khomsan, Totok Agung (Guru Besar Pertanian Universitas Jenderal Soedirman Purwokerto) terdapat beberapa strategi yang dapat dilakukan untuk mengantisipasi krisis pangan, yakni: pertama, kelompok tani perlu menghidupkan kembali lumbung padi, sebagian panen disimpan; kedua, memanfaatkan semua lahan potensial yang ada untuk produksi pangan, baik tanaman, ternak, maupun ikan; ketiga, meningkatkan indeks pertanaman (IP) termasuk di lahan sawah. Bahwa secara nasional, kita memiliki luas lahan baku 7,4 juta hektar, luas panen padi kita tiap tahun sekitar 11 juta hektare. Berarti IP rata-rata masih 150; keempat, memanfaatkan lahan-lahan kering tegalan yang belum optimal untuk produksi pangan ${ }^{38}$.

Peneliti setuju dengan Ali Khosman dan Totok Agung. Petani, peternak perlu didukung karena keterbatasan modal, lahan yang dimiliki, begitu juga dengan kendala cuaca di Indonesia. Dukungan tersebut tentu akan membawa dampak positif, ketahanan pangan terwujud, petani sejahtera, dan jangka panjangnnya dapat mewujudkan kemandirian pangan. Wabah corona ini sangat berdampak bukan hanya pada kesehatan masyarakat, tetapi juga pada sosial ekonomi masyarakat juga lingkungan hidup. Kegiatan masyarakat jadi terbatas, sekolah, kerja, ibadah dilakukan dari rumah, pangan berpotensi menjadi krisis. Banyaknya karyawan yang dirumahkan dan

37 Ali Khomsan, Opini "Ketahanan Pangan dan Gizi di Tengah Covid-19" https://mediaindonesia.com/read/detail/304831-ketahanan-pangan-dan-gizi-di-tengah-covid-19 (diakses tanggal 12 Juli 2020)

${ }^{38}$ Totok Agung, "Pakar: Perlu Antisipasi Krisis Pangan di Tengah Pandemi Covid-19" https://jateng.antaranews.com/berita/310520/pakar-perlu-antisipasi-krisis-pangan-di-tengah-pandemicovid-19 (diakses tanggal 12 Juli 2020) 
langsung di PHK, sehingga kehidupan masyarakat menjadi sulit. Menurut Andreas Tedy, Environmental law related to natural resource management in Indonesia should have to achieve national food and energy security. It needs a systemic relaxation of legal system (legal substance, legal structure, and legal culture) towards advancing food and energy sovereignty. Such relaxation should proceed, not only at the legislative drafting stage, but also at judicative stage in order to accelerate the people awareness stage heading to the ius constituendum ${ }^{39}$.

Untuk mengantisipasi kejadian yang lebih buruk lagi (misalnya terjadi kelaparan) maka sudah saatnya kita menggerakkan para petani untuk diberdayakan melalui penyuluhan untuk mendorong, memotivasi, membangkitkan kesadaran akan potensi yang dimiliki untuk meningkatkan hasil pertanian dengan dibantu dari dana desa yang tersedia.40 Semua ini adalah tanggung jawab kita bersama Pemerintah melalui Kementerian Pertanian untuk memenuhi kebutuhan dasar pangan di masa pandemic ini. Berbicara tentang kebutuhan dasar pangan tidak terlepas dari makanan pokok beras. Padahal adad beberapa makanan pokok yang hamper sama dengan beras seperti sagu. Sagu bisa dijadikan alternative pengganti beras yang diproduksi tidak mencukupi. Dengan kondisi seperti saat ini seharusnya masyarakat desa yang selama ini menanam padi diperkenalkan juga untuk menanam palawija yaitu tanaman pohon sagu sebagai pengganti makanan beras.

Menurut pendapat Peneliti, substitusi pangan juga harus segera disosialisasikan, walaupun Peneliti yakin merubah pola makan masyarakat Indonesia tentu butuh waktu lama. Berbicara tentang kebutuhan dasar pangan tidak terlepas dari makanan pokok beras. Padahal terdapat beberapa makanan pokok yang hamper sama dengan beras seperti sagu. Sagu bisa dijadikan alternative pengganti beras yang diproduksi tidak mencukupi. Dengan kondisi seperti saat ini seharusnya masyarakat desa yang selama ini menanam padi diperkenalkan juga untuk menanam palawija yaitu tanaman pohon sagu sebagai pengganti makanan beras. Selain itu, terdapat beberapa daerah yang sudah memanfaatkan tanaman palawija sebagai bahan makanan pokoknya seperti tanaman pohon sagu yang saat ini digunakan dibeberapa daerah sebagai makanan pokok seperti daerah Maluku, Papua dan sebagian wilayah Sumatera dan Jawa. Menurut pengalaman Peneliti, sagu juga menjadi salah satu sumber dalam mengatasi kekurangan pangan, karena pohon sagu sangat mudah ditanam di hampir seluruh wilayah Indonesia, kandungan nutrisi dalam sagu relatif lengkap. Di dalam sagu, terdapat karbohidrat dalam jumlah yang cukup banyak.

Lahan tanaman sagu di Indonesia tahun 2020 adalah sebesar 318.563 HA dimana yang terbesar pertama adalah diwilayah Papua 158.084 HA yang kedua adalah Propinsi Riau 75.192 yang ketiga adalah Maluku 39.359 HA sehingga sangat besar potensi pengembangannya sebagai pangan alternative, dan disinilah masyarakat petani diberdayakan guna meningkatkan produktifitasnya.41 Sedangkan saat ini makanan pokok utama masyarakat Indonesia sebagian besar adalah beras, yang mana Data konsumsi beras untuk seluruh Indonesia adalah 2,5 juta ton per bulan, jika dikalikan per

${ }^{39}$ Andreas Tedy Mulyono. Relaksasi Pengelolaan Sumber Daya Alam Dalam Diskursus Hukum Lingkungan Hidup Di Indonesia. Law Review Volumen XIX, No. 1 -Juli 2019. HIm. 25.

${ }^{40}$ Undang-Undang Nomor 6 Tahun 2014 tentang Desa

${ }^{41}$ https://www.pertanian.go.id/home/index.php?show=repo\&fileNum=235 
tahun sebesar 30 Juta ton per tahun. ${ }^{42}$ Perkiraan produksi beras tahun 2020 per bulan sebesar $+/-3$ juta ton sehingga apabila konsumsi beras 2,5 juta ton per bulan maka masih ada surplus/cadangan sebesar 500 ton. ${ }^{43}$

Bertambah banyaknya jumlah manusia yang memerlukan tanah untuk tempat perumahan, juga kemajuan dan perkembangan eknomi, sosial budaya dan teknologi menghendaki pula tersedianya tanah yang banyak umpamanya untuk perkebunan, peternakan, pabrik-pabrik, perakntoran, tempat hiburan dan jalan-jalan untuk perhubungan44. Kurangya lahan juga menyebabkan salah satu permasalahan ketahanan pangan, karena petani kesulitan untuk mendapatkan tanah untuk bertani. Menurut Joko Satrianto bahwa perlu dilakukan penataan kembali untuk mewujudkan atanah sebagai sumber kesejahteraan rakyat, untuk mewujudkan kehidupan yang lebih berkeadilan dan keberlanjutan. Selain, itu optimalisasi pengusahaan, penggunaan dan pemanfaatan tanah diperlukan untuk meningkatkan kualitas lingkungan hidup dan menciptakan ketahanan pangan ${ }^{45}$. Persoalan kecukupan pangan dalam rangka ketahanan pangan nasional salah satu di antaranya adalah semakin berkurangnya lahan pertanian karena alih fungsi, menjadi daerah perindustrian, perumahan, dan kebutuhan lahan lainnya. Salah satu alternatif solusinya adalah pengembangan wanatani. Dalam wanatani, hutan dikelola untuk kegiatan pertanian oleh masyarakat atau petani di sekitar hutan tanpa merusak fungsi hutan, bahkan kegiatan produktif ini diharapkan juga meningkatkan kelestarian hutan ${ }^{46}$.

Menurut pendapat Peneliti, keterbatasan lahan pertanian juga menjadi permasalahan untuk mewujudkan ketahanan pangan di Indonesia. Bertambah banyaknya jumlah manusia yang memerlukan tanah untuk tempat perumahan, juga kemajuan dan perkembangan eknomi, sosial budaya dan teknologi menghendaki pula tersedianya tanah yang banyak umpamanya untuk perkebunan, peternakan, pabrikpabrik, perakntoran, tempat hiburan dan jalan-jalan untuk perhubungan ${ }^{47}$. Kurangya lahan juga menyebabkan salah satu permasalahan ketahanan pangan, karena petani kesulitan untuk mendapatkan tanah untuk bertani. Menurut Joko Satrianto, optimalisasi pengusahaan, penggunaan dan pemanfaatan tanah diperlukan untuk meningkatkan kualitas lingkungan hidup dan menciptakan ketahanan pangan ${ }^{48}$. Persoalan kecukupan pangan dalam rangka ketahanan pangan nasional salah satu di antaranya adalah semakin berkurangnya lahan pertanian karena alih fungsi, menjadi daerah

42 https://money.kompas.com/read/2019/12/31/181626826/kementan-prediksi-nilai-

konsumsi-pangan- naik-di-2020.

43 https://industri.kontan.co.id/news/kementan-sebut-produksi-beras-capai-tiga-juta-tonper-bulan-di- tahun-

44 Satya Putra, (2019). Reforma Agraria Hambatan Dan Tantangan Di Kabupaten Karawang. Jurnal Ilmiah Hukum De’jure: Kajian Ilmiah Hukum, 4 (1), 110-134. https://doi.org/10.35706/dejure.v4i1.1865 . Hlm. 112.

${ }^{45}$ Satrianto Wibowo, (2016). Pendayagunaan Tanah Terlantar Sebagai Obyek Landreform Untuk Lahan Pertanian Dikaitkan Dengan Asas Keadilan. Jurnal Ilmiah Hukum DE'JURE: Kajian Ilmiah Hukum, 1(2), 286-300. https://doi.org/10.35706/dejure.v1i2.510 . Hlm. 288.

46 Moch. Najib Imanulla. (2003), Politik Hukum Ketahanan Pangan Nasional (Kajian Sinkronisasi Politik Undang-Undang Hak Pvt Dan Undang-Undang Pangan). Yustisia Vol. 2 No. 1 Januari-April 2013. Hlm. 90.

47 Satya Putra, S (2019). Reforma Agraria Hambatan Dan Tantangan Di Kabupaten Karawang. Jurnal Ilmiah Hukum DE'JURE: Kajian Ilmiah Hukum,4(1), 110-134. https://doi.org/10.35706/dejure.v4i1.1865. Hlm. 112.

48 Satrianto Wibowo, (2016). Pendayagunaan Tanah Terlantar Sebagai Obyek Landreform Untuk Lahan Pertanian Dikaitkan Dengan Asas Keadilan. Jurnal Ilmiah Hukum DE'JURE: Kajian Ilmiah Hukum, 1(2), 286-300. https://doi.org/10.35706/dejure.v1i2.510 . Hlm. 288. 
perindustrian, perumahan, dan kebutuhan lahan lainnya. Menurut Imanulla, Salah satu alternatif solusinya adalah pengembangan wanatani. Dalam wanatani, hutan dikelola untuk kegiatan pertanian oleh masyarakat atau petani di sekitar hutan tanpa merusak fungsi hutan, bahkan kegiatan produktif ini diharapkan juga meningkatkan kelestarian hutan ${ }^{49}$.

Peneliti melihat bahwa pemberdayaan masyarakat desa mencapai kemandirian dalam pemenuhan kebutuhan pokoknya masih harus terus diupayakan oleh pemerintah, dan impor beras saat ini sudah menjadi tradisi bagi pemerintah untuk memenuhi kebutuhan pangan dalam negeri, sesuai dengan Bab I Pasal 1 nomor 12 Undang-Undang nomor 6 tahun 2014 tentang Desa. Dengan wabah covid-19 ini kondisi perekonomian semakin menurun karena aktifitas ekonomi dihentikan sementara waktu akibatnya banyak pekerja non formal yang paling terpukul, menurut Kepala Badan Pusat Statistik RI (BPS), bahwa jumlah pekerja informal sebanyak 70,49 juta, per Agustus 2019 atau sebanyak 55,72\% dari total angkatan kerja di Indonesia, pekerja non formal adalah mereka yang berusaha sendiri, berusaha dibantu buruh tidak tetap, pekerja bebas, dan pekerja tidak dibayar. Adapun jumlah pekerja formal, di periode yang sama, sebanyak 56,02 juta orang. Jumlah tersebut setara $44,28 \%$ dari totalnya angkatannya kerjanya di Indonesia. ${ }^{50}$

Jumlah pekerja non formal yang sangat besar tersebut menurut hemat Peneliti akan menjadi tenaga kerja yang sangat potensial dan dapat diberdayakan guna membantu pemerintah pusat dan pemerintah daerah dalam menyediakan pangan dalam masa pandemi ini. Setiap rumah tangga juga dapat menanam sayuran misalnya di halaman rumah mereka masing-masing guna mencukupi kebutuhan pangan mereka, sehingga mengurangi pengeluaran untuk membeli kebutuhan sayur mayur. Dalam skala yang lebih luas/nasional Kementerian Pertanian dapat menjadi motor penggerak masyarakat terutama di pedesaan dalam pertanian maupun peternakan, sehingga masyarakat dapat memenuhi kebutuhan dasar pangan secara mandiri.

Hal ini perlu disiapkan karena dalam masa pandemic ini beberapa negara produsen pangan yang biasanya mengekspor kebutuhan pokok seperti beras dan terigu sudah mulai membatasi atau bahkan menutup sementara pasar ekspor komoditi tertentu, untuk memastikan stok/ketersediaan dalam negeri mereka tercukupi. Seperti Vietnam dan Thailand yang selama ini disebut sebagai lumbung beras di Asia Tenggara tentu akan mengamankan pasokan beras untuk negaranya. Perlu diketahui bahwa Pemerintah telah menyiapkan anggaran sebesar Rp. 405.1 triliun untuk penanggulangan Covid-19 yang digunakan untuk kesehatan Rp. 75 triliun, tambahan jaring pengaman social Rp. 110 triliun, dukungan bagi industry Rp. 70,1 triliun dan program pemulihan ekonomi Rp. 150 triliun. Berdasarkan data BPS, rumah tangga miskin tersebar di daerah perkotaan sebesar 6,56 persen atau 9,86 juta dan daerah pedesaan 12,60 persen atau 14,93 juta, yang mayoritas bekerja disektor pertanian. Sedangkan, menurut Badan Ketahanan Pangan, setidaknya 76 kabupaten/kota masuk kategori daerah rawan pangan. ${ }^{51}$

Beban pemerintah untuk memenuhi kebutuhan pangan warganya yang berjumlah kurang lebih 267 juta jiwa, menjadi berat terlebih di masa pandemic saat ini. Untuk ketahanan pangan dimasa covid-19 ini Kementan memberikan bantuan kepada

49 Moch. Najib Imanulla. Politik Hukum Ketahanan Pangan Nasional (Kajian Sinkronisasi Politik Undang-Undang Hak Pvt Dan Undang-Undang Pangan). Yustisia Vol. 2 No. 1 Januari-April 2013. Hlm. 90.

${ }^{50} \mathrm{https}: / /$ www.topbusiness.id/26116/jumlah-pekerja-informal-7049-juta-orang (4/11/19)

${ }^{51} \mathrm{https}$ //www.antaranews.com/berita/1429408/menguji-ketahanan-pangan-nasional-di-tengahwabah-corona) $18 / 04 / 2020$ 
para petani di masa pandemi covid-19 saat ini nantinya akan berbentuk sarana produksi (saprodi) pertanian seperti benih, pupuk, dan obat-obatan. Bantuan yang dikucurkan bukan dalam bentuk uang tunai. "Bantuan langsung tapi bukan dalam bentuk pendanaan. Bantuannya adalah dalam bentuk saprodi dengan nilai kurang lebih Rp300 ribu di dalamnya ada pupuk bibit dan obat-obatan. Tentu saja program ini adalah program yang mudah dilakukan, realistis untuk bisa ditanam kemudian harus cepat menghasilkan karena ini untuk membantu pasar.52

Selain Kementan, Kementerian Desa, Pembangunan Daerah Tertinggal, dan Transmigrasi (selanjutnya disebut Kemendes PDTT) juga terlibat dalam mewujudkan ketahanan pangan. Kemendes PDTT mengajukan intensifikasi 1,8juta hectare lahan pertanian yang terletak di 3,2 juta hektare kawasan transmigrasi yang tersebuar di seluruh wilayah Indonesia. Tahap pertama, ada 509.000 hektare lahan yang telah dinyatakan siap dan memenuhi syarat pelaksanaan intensifikasi lahan pertanian. Syarat intensifikasi meliputi ketersediaan lahan, tenaga kerja, rice miling dan irigasi, bibit unggul dan pupuk, serta off taker dan mitra kerja. Intensifikasi akan dimulai pada musim tanam kemarau Mei-Juni 2020 untuk jenis padi yang tahan pasokan minim air seperti padi gogo dan nantinya pada musim tanam September-Desember 2020 akan ditanam jenis padi unggul yang sarat kebutuhan air karena pada saat itu umumnya akan banyak diguyur hujan ${ }^{53}$.

Dalam kaitan dengan hal ini juga, Menteri Desa, Pembangunan Daerah Tertinggal dan Transmigrasi Republik Indonesia mengeluarkan Surat Edaran Nomor 8 tahun 2020 tanggal 24 Maret 2020, dan diperbaharui melalui Surat Edaran Nomor 11 tahun 2020 tanggal 30 Maret 2020 mengenai Penegasan Padat Karya Tunai Desa, sebagai upaya pemerintah tetap memberdayakan masyarakat desa dalam menghadapi covid-19 ini.

Menurut Posman Sibuea (Guru Besar Ilmu Pangan Unika Santo Thomas Medan, Sumut) berpendapat tentang solusi untuk mengatasi penurunan jumlah pangan di Indonesia yakni:

1. Pertama, Menata ulang peta distribusi pangan. Dalam waktu dekat ini pemerintah harus memperbarui peta distribusi dan kerentanan ketahanan pangan guna memastikan skema bantuan pangan yang diberikan. Saat ini sangat dibutuhkan peta distribusi pangan yang rinci, meliputi sentra produksi, indikator tingkat kerentanan ketahanan pangan, dan kelancaran pasokan terkait infrastruktur jalan dan transportasi;

2. Kedua, manajemen cadangan pangan darurat. Sampai saat ini Indonesia belum mempunyai skema cadangan pangan darurat (CPD). Di tengah darurat Covid19 saat ini, sesungguhnya bahan makanan harus tersedia dengan jumlah dan mutu yang baik serta harga terjangkau. Namanya darurat, makanannya harus memiliki gizi khusus untuk mengembalikan pemulihan korban ${ }^{54}$;

Peneliti sependapat dengan Posman, kekayaan sumber daya alam, tanah yang subur di Indonesia menjadi pendukung terwujudnya ketahanan pangan di Indonesia. Selain peran Pemerintah, Mahasiswa/i pada program studi pertanian dapat juga

${ }^{52} \mathrm{https}: / /$ mediaindonesia.com (12/6/20)

53 Dani Prabowo "Cegah Krisis Pangan karena Pandemi Covid-19, Ini yang Dilakukan Kemendes" $\quad$ https://nasional.kompas.com/read/2020/05/14/15455321/cegah-krisis-pangan-karenapandemi-covid-19-ini-yang-dilakukan-kemendes (diakses tanggal 12 Juli 2020)

54 Posman Sibuea Opini "Darurat Pangan Saat Pandemi Covid-19", https://analisis.kontan.co.id/news/darurat-pangan-saat-pandemi-covid-19 (diakses tanggal 12 Juli 2020) 
dilibatkan, misalnya melalui Kuliah Kerja Nyata di desa tersebut. Selain itu, menurut Noer, partisipasi masyarakat dalam pembangunan ketahanan pangan adalah melalui pemberdayaan kelembagaan lokal seperti lumbung desa dan peningkatan peran masyarakat dalam penyediaan pangan. Hal tersebut perlu dipertimbangkan sebagai salah satu upaya mewujudkan ketahanan pangan di Indonesia ${ }^{55}$. Menurut Ichsan, Dosen Fakultas Perikanan dan Ilmu Kelautan Universitas Padjajaran, masyarakat juga perlu berpartisipasi aktif pada kegiatan urban farming56.

Beradasarkan ketentuan Undang-Undang Nomor 24 Tahun 2007 Tentang Penanggulangan Bencara Pasal 60 ayat 1 dan 2 mengatakan bahwa pada dasarnya menjadi tanggung jawab bersama antara pemerintah dan pemerintah daerah mendorong partisipasi masyarakat di dalamnya. ${ }^{57}$ Bagaimana bentuk tanggung jawab Pemerintah dalam membantu masyarakat agar supaya tetap hidup dan bisa makan sehari-hari, untuk itu di pasal 8 Undang-Undang 24 tahun 2007 Pasal 8 dikatakan sebagai berikut: Tanggung jawab pemerintah daerah dalam penyelenggaraan penanggulangan bencana meliputi:

a. penjaminan pemenuhan hak masyarakat dan pengungsi yang terkena bencana sesuai dengan standar pelayanan minimum;

b. perlindungan masyarakat dari dampak bencana;

c. pengurangan risiko bencana dan pemaduan pengurangan risiko bencana dengan program pembangunan; dan

d. pengalokasian dana penanggulangan bencana dalam Anggaran Pendapatan dan Belanja Daerah yang memadai.

Berdasarkan pasal 6 huruf f Undang-Undang 24/2007 diatur tentang tanggung jawab Pemerintah dalam penyelenggaraan penanggulangan bencana meliputi: pengalokasian anggaran penanggulangan bencana dalam bentuk dana siap pakai; dan pengalokasian anggaran penanggulangan bencana dalam Anggaran Pendapatan dan Belanja Negara yang memadai; (Psl. 7 huruf e). Dana Siap Pakai yang bersumber dari APBN tersebut dialokasikan pada anggaran BNPB (PP Nomor 22 Tahun 2008 Pasal 6 ayat (2).

Dengan kondisi pandemi sekarang ini menurut hemat Peneliti pemerintah dan pemerintah daerah harus serius menangani masalah pangan ini, karena UndangUndang sampai dengan Peraturan Pemerintah, Keputusan Presiden sudah disediakan, tinggal bagaimana kemauan pemerintah dan pemerintah daerah dapat mengelaborasi ketentuan atau aturan pangan yang sudah di nyatakan dalam Undang-Undang, Peraturan Pemerintah maupun Keputusan Presiden.

Pemerintah juga seyogyanya mempersiapkan ancaman krisis akibat pandemi Corona yakni dengan mempersiapkan rencana pembukaan sawah baru atau program cetak sawah di lahan gambut Kalimantan Tengah. Menteri Koordinator Bidang Perekonomian, Airlangga Hartarto mengatakan bahwa hingga saat ini sudah ada sekitar

55 Mohammad H.R.P. Noer. Meningkatkan Peran Masyarakat dala Penyediaan Pangan. (Jakarta: Bulog, 1995).

${ }^{56}$ Kantor Komunikasi Publik. Urban Farming, Solusi Ketahanan Pangan di Masa Pandemi Covid-19. (16 Feb 2021)) Diakses dari https://www.unpad.ac.id/2021/02/urban-farming-solusiketahanan-pangan-di-masa-pandemi-covid-19/ diakses tanggal 19 Desember 2021.

${ }^{57} \mathrm{https}: / /$ www.hukumonline.com $(15 / 03 / 20)$ 
255 ribu hektare lahan gambut yang berpotensi dikembangkan menjadi areal persawahan ${ }^{58}$.

\section{Kesimpulan}

Berdasarkan pembahasan di atas, kesimpulan yang diperoleh yakni ketahanan pangan di masa Pandemi Covid-19 adalah tanggung jawab bersama, tanggung jawab Pemerintah Pusat melalui Kementerian yang berwenang, tanggung jawab Pemerintah Daerah, dan juga peran dari masyarakat. Kementerian Pertanian memiliki tanggung jawab untuk kesejahteraan petani. Petani di masa Covid-19 tentu mengalami penurunan modal berupa uang. Dana desa juga sebaiknya digunakan untuk mendukung program pertanian, untuk mendukung permodalan. Hasil pertanian yang baik, hasil yang berkualitas akan membawa manfaat, ekspor hasil pertanian akan meningkat, dan juga akan mampu mengurangi impor hasil pertanian.

Kesimpulan kedua, insentif kepada petani dapat diberikan dalam pelbagai bentuk. Insentif berupa permodalan dengan bunga $0 \%$ (nol per seratus), uang tunai, obat tanaman, bibit tanaman sangat dibutuhkan oleh petani. Pendistribusian, pembelian hasil pertanian dengan harga yang wajar, bahkan dengan harga yang menguntungkan petani juga merupakan bentuk insentif, dan bentuk nyata dukungan kepada petani untuk mewujudkan ketahanan pangan.

\section{Daftar Pustaka}

\section{Peraturan Perundang-undangan:}

Undang-Undang Dasar Negara Republik Indonesia Tahun 1945

Republik Indonesia, Undang-undang Wabah Penyakit Menular, Undang-Undang Nomor 4 Tahun 1984 Lembaran Negara Republik Indonesia Tahun 1984 Nomor 20, Tambahan Lembaran Negara Republik Indonesia Nomor 3273

Republik Indonesia, Undang-undang Pengesahan International Covenant On Economic, Social and Cultural Rights (Kovenan Internasioal Tentang Hak-Hak Ekonomi, Sosial dan Budaya

Undang-Undang Nomor 11 Tahun 2005 Lembaran Negara Republik Indonesia Tahun 2005 Nomor 118, Tambahan Lembaran Negara Republik Indonesia Nomor 4557

Republik Indonesia, Undang-undang Penanggulangan Bencana, Undang-Undang No. 24 tahun 2007 Lembaran Negara Republik Indonesia Tahun 2007 Nomor 66, Tambahan Lembaran Negara Republik Indonesia Nomor 4723

Republik Indonesia, Undang-undang Cegah Alih Fungsi Lahan Pertanian Demi Ketahanan Pangan, Undang-Undang Nomor 41 Tahun 2009 Lembaran Negara Republik Indonesia Tahun 2009 Nomor 149, Tambahan Lembaran Negara Republik Indonesia Nomor 5068

${ }^{58}$ Dimas Jarot Bayu "Jokowi Terus Kebut Program Cetak Sawah di Lahan Gambut Kalimantan" https://katadata.co.id/berita/2020/05/13/jokowi-terus-kebut-program-cetak-sawah-di-lahan-gambutkalimantan (diakses tanggal 12 Juli 2020) 
Republik Indonesia, Undang-undang Pangan, Undang-Undang Nomor 18 Tahun 2012 LembaranNegara Republik Indonesia Tahun 2012 Nomor 227, Tambahan Lembaran Negara Republik Indonesia Nomor 5360

Republik Indonesia, Undang-undang Desa, Undang-Undang Nomor 6 Tahun 2014 Lembaran Negara Republik Indonesia Tahun 2014 Nomor 7, Tambahan Lembaran Negara Republik Indonesia Nomor 5495

Republik Indonesia, Undang-undang Kekarantinaan Kesehatan, Undang-Undang Nomor 6 Tahun 2018 Lembaran Negara Republik Indonesia Tahun 2018 Nomor 128, Tambahan Lembaran Negara Republik Indonesia Nomor 6236

Republik Indonesia, Peraturan Pemerintah Nomor 22 Tahun 2008 Pendanaan dan Pengelolaan Bantuan Bencana

Peraturan Pemerintah Nomor 22 Tahun 2008 Tentang Pendanaan dan Pengelolaan Bantuan Bencana, Lembaran Negara Republik Indonesia Tahun 2008 Nomor 43, Tambahan Lembaran Negara Republik Indonesia Nomor 4829

Republik Indonesia, Peraturan Pemerintah Jaminan Luasan Lahan Pertanian, Peraturan Pemerintah Nomor 655 Tahun 2019, Lembaran Negara Republik Indonesia Tahun 2019 Nomor 170, Tambahan Lembaran Negara Republik Indonesia Nomor 6389

Republik Indonesia, Peraturan Pemerintah Pembatasan Sosial Berskala Besar dalam Rangka Percepatan Penanganan Corona Virus Disease 2019 (Covid-19), Peraturan Pemerintah Nomor 21 Tahun 2020, Lembaran Negara Republik Indonesia Tahun 2020 Nomor 91, Tambahan Lembaran Negara Republik Indonesia Nomor 6487

Republik Indonesia, Keputusan Presiden Nomor 7 Tahun 2020 Tentang Gugus Tugas Percepatan Penanganan Corona Virus Desease 2019 (Covid-19)

Keppres no. 11 tahun 2020 tanggal 31 Maret 2020 tentang kedaruratan kesehatan masyarakat

Republi Indonesia, Keppres no. 12 Tahun 2020 tanggal 13 April 2020 Tentang Penetapan Bencana Non Alam Penyebaran Corona Virus Desease 2019 (Covid 19) Sebagai Bencana Nasional.

Repubik Indonesia, Peraturan Menteri Kesehatan Pedoman Pembatasan Sosial Berskala Besar dalam Rangka Percepatan Penanganan Corona Virus Disease 2019 (Covid19), Peraturan Menteri Kesehatan Nomor 9 Tahun 2020, Berita Negara Republik Indonesia Tahun 2020 Nomor 326.

\section{Buku:}

Azwar, Saifudin. 2004. Metode Penelitian. Yogyakarta: Pustaka Pelajar.. 
M. Hadjon. Philipus. 1987 Perlindungan Hukum bagi Rakyat Indonesia.Surabaya: PT Bina Ilmu,

Mahmud Marzuki,Peter. 2005. Penelitian Hukum, Bandung:Kencana..

Molcong, 2006. Metodologi Penelitian Kualitatif, Rosda Karya, Bandung: Rosda Karya.

Noer, Mohammad H.R.P. 1995. Meningkatkan Peran Masyarakat dala Penyediaan Pangan. Jakarta: Bulog

Rahardjo, Sajipto. 2010. Penegakan Hukum Progresif. Jakarta; Kompas.

Rahardjo, Satjipto. 2000. Ilmu Hukum. Bandung: PT Citra Aditya Bakti.

Wahono. Francis. 2011. Ekonomi Politik Pangan. Jakarta: Bina Desa dan Yogyakarta: Cinde Books.

\section{Karya Ilmiah:}

A Budianto, RK Karo. Marapu Customary Law Reconstruction Through The Establishment Of Regional Regulations As An Attempt Of Human Rights Protection Againts The Native Sumba Society. Multicultural Education, 2021. DOI: 10.5281/ZENODO.4767980

Budianto, A. (2018). Formalin Dalam Kajian Undang-Undang Kesehatan; Undang-Undang Pangan Dan Undang-Undang Perlindungan Konsumen Formalin In Health, Food And Consumer Protection Laws Studies. Jurnal Legislasi Indonesia, 8(1), 151-172.

Budianto, A. (2020). Legal Research Methodology Reposition in Research on Social Science. International Journal of Criminology and Sociology, 9, 1339-1346.

Dr. Ina Heliany, S.H., M.H, D. S. P. S. M. dan. (2018). PERANAN LEMBAGA SWADAYA MASYARAKAT (LSM) TERHADAP PEMBANGUNAN POLITIK DAN DEMOKRASI DI INDONESIA. Jurnal Ilmiah Hukum DE'JURE: Kajian Ilmiah Hukum, 3(1), 131-146. https:/ / doi.org/10.35706/dejure.v3i1.1890

Ginting, J., \& Raportina, H. (2021). Implikasi Hukum Putusan Mahkamah Konstiusi Nomor 16/Puu-Xviii/2020 Terhadap Notaris Sebagai Saksi Dalam Kasus Pidana [The Implication of Constitutional Court Decision Number 16/PUU-XVIII/2020 towards Notary as A Witness in Criminal Case]. Law Review, (2), 218-240.

Made Oka Adnyana. Lintasan Dan Marka Jalan Menuju Ketahanan Pangan Terlanjutkan Dalam Era Perdagangan Bebas. Pengembangan Inovasi Pertanian 1 (1). 2008: 17-46.

Moch. Najib Imanulla. Politik Hukum Ketahanan Pangan Nasional (Kajian Sinkronisasi Politik Undang-Undang Hak Pvt Dan Undang-Undang Pangan). Yustisia Vol. 2 No. 1 Januari-April 2013.

Mulyono. Andreas Tedy. Relaksasi Pengelolaan Sumber Daya Alam Dalam Diskursus Hukum Lingkungan Hidup Di Indonesia. Law Review Volumen XIX, No. 1 - Juli 2019

Nuryadi, S.H., M.H, H. D. (2016). Teori Hukum Progresif Dan Penerapannya Di Indonesia. Jurnal Ilmiah Hukum DE'JURE: Kajian Ilmiah Hukum, 1(2), 394-408. https://doi.org/10.35706/dejure.v1i2.515

Satya Putra, S.H., M.H, P. (2019). Reforma Agraria Hambatan Dan Tantangan Di Kabupaten Karawang. Jurnal Ilmiah Hukum DE'JURE: Kajian Ilmiah Hukum,4(1), 110-134. https://doi.org/10.35706/dejure.v4i1.1865

Sulhani Hermawan. Tinjauan Keadilan Sosial Terhadap Hukum Tata Pangan Indonesia. Mimbar Hukum Volume 24, No. 3, Oktober 2012.

\section{Sumber Lainnya:}

https://analisis.kontan.co.id/news/darurat-pangan-saat-pandemi-covid-19 
https://industri.kontan.co.id/news/kementan-sebut-produksi-beras-capai-tiga-jutaton-per-bulan-di- tahun-

https://jateng.antaranews.com/berita/310520/pakar-perlu-antisipasi-krisis-pangandi-tengah-pandemi-covid-19

https://mediaindonesia.com/read/detail/304831-ketahanan-pangan-dan-gizi-ditengah-covid-19

https://mediaindonesia.com/read/detail/310494-bantuan-kementan-untuk-petanidalam-bentuk-saprodi $(12 / 6 / 2020)$

https:// money.kompas.com/read/2019/12/31/181626826/kementan-prediksi-nilaikonsumsi-pangan- naik-di-2020.

https://nasional.kompas.com/read/2020/05/14/15455321/cegah-krisis-pangankarena-pandemi-covid-19-ini-yang-dilakukan-kemendes

https://news.detik.com/berita/d-4941875/data-corona-terkait-indonesia-16-maret2020)

https://www.antaranews.com/berita/1429408/menguji-ketahanan-pangan-nasionaldi-tengah-wabah-corona

https://www.bbc.com/indonesia/indonesia-51897307)16-03-2020,.

https://www.cnbcindonesia.com/news/20200312075307-4-144247/who-nyatakanwabah-covid-19 (12 Maret 2020)

https://www.hukumonline.com/berita/baca/lt5e6dfa1f0a8c8/ketentuan-penetapanbencana-nasional-menurut-undang-undang?page=all (15 Maret 2020)

https://www.pertanian.go.id/home/index.php?show=repo\&fileNum=235

https://www.topbusiness.id/26116/jumlah-pekerja-informal-7049-juta-orang $(4 / 11 / 19)$

https://www.unpad.ac.id/2021/02/urban-farming-solusi-ketahanan-pangan-dimasa-pandemi-covid-19/ 